\title{
A Comparative Study of Aesthetic, Economic and Political Values of Undergraduate Students
}

\author{
Kruti Sharma
}

\section{ABSTRACT:}

This study focused on, three out of six basic interests/ motives in personality: Aesthetic, Economic and Political values- of 300 undergraduate male \& female students, studying in FineArts and Business Administration streams. The sample was equally distributed among two of the streams and gender. Two way Analysis of Variance as a part of statistical analysis was employed, in order to examine the role of values. Results indicated that, students of Fine-Arts stream had significantly greater Aesthetic value than Business Administration students and Aesthetic value was also seen higher in females than males. It was also found that Economic value was greater in Business Administration students as compared to Fine-Arts students and it did not differ at gender level. Lastly, there was no significant difference observed in terms of Political value, concerning two of the streams; however male students seemed to have higher Political Value than female students.

\section{Keywords: Values, Aesthetic Value, Economic Value, Political Value, Undergraduates.}

\section{INTRODUCTION:}

For millennia, philosophers, sociologists, psychologists, and others have tried to figure out just exactly what values are. We have them; all humans do. The word comes from the Latin"valeo", which means- to be strong. Values can be likened to roots that keep a tree upright and anchored against the onslaught of the elements. Our values steady us against the maelstrom of everyday life.Values are defined broadly as 'the principles and fundamental convictions which act as general guides to behavior, the standards by which particular actions are judged as good or desirable(Halstead and Taylor, 2000).

In 1931, psychologist Gordon Allport came up with a list of what he called traits, what we would now call values, easily recognized consistencies that are unique to you and define your life. Allport also devised six categories of values: (1) Theoretical: truth; (2) Economic: usefulness; (3) Aesthetic: harmony and beauty; (4) Social: love; (5) Political: power and leadership; (6) Religious: unity or moral excellence.

According to a study examined by Allport K: Vernon, 1931; Super, 1969, values have been related to interests and other motivational notions, and used to explain differences in people's occupational behavior, in particular vocational choice. Other findings indicate that personal values do influence human behavior and the way of living (England 1975, Rokeach 1973, Singhapakdi and Vitell 1993, Guth and Tagiuri 1987, Fritzsche 1995, Finegan 1994, Eaton and Giacomino 2000, 2001).

\footnotetext{
${ }^{1}$ Research Associate/ Lecturer, Psychology, Ahmedabad, Gujarat, India
}

(C) 2015, K Sharma; licensee IJIP. This is an Open Access Research distributed under the terms of the Creative Commons Attribution License (http://creativecommons.org/licenses/by/2.0), which permits unrestricted use, distribution, and reproduction in any Medium, provided the original work is properly cited. 
The psychological point of view classifies values into implicit values which are internal values and explicit values which are so clearly verbalized that others can make judgments about them (Mahjabeen, and Mozumder, 2000).In a cross cultural study, Karim (1990) observed that age, sex and cultural differences between Indian and Bangladeshi adolescents' affects political, religious and aesthetic values. Cross cultural model of values indicates that values are selfimposed criteria that balance between individual needs, the coordination of social interaction, and group survival.

Differences in religious, economic and political values have also been recorded between ingoing and outgoing university students by Rahman and Wadud (1983). The college/university honors students had higher economic and aesthetic values (Karim, and Rahman, 2001). Between Hindu and Muslim students similar findings were found by Khanam(1993). Moeed \& Murshad (1986) noticed the change of values as a result of the education system of the university. Their findings indicate differences between the male \& female students in theoretical \& aesthetic values. Timmer \& Kahle (1983) have also stated that individual's age, sex, race, and social-class were highly correlated with value selection. Mohsin(1955) and Chowdhury's (1958) study on culture produced results which showed the values changed with the change in profession. Zaman (1973) compared the values of teachers and students and found significant changes of values between two generations. Dunn, Bliss, \& Siipola(1958), examined the effect of values on associative patterns and concluded that individual value can constitute a "critical determinant" of cognitive processes; MacKinnon (1964), reported that creative architects and scientists were high in Aesthetic values. In a Study of Values Adjusted for Sex and Variability Differences, by Stanley, Julian C. (1953), women were observed being more religious, aesthetic, \& social and men being more theoretical, political \&economic.

The above literature shows that values affect both individuals' well-being and the well-being of others. And it also helps the learner to adjust with the society. In the light of the previous findings it can be said that people from different nations have different values according to the society and culture. Values may vary from person to person and time to time. Family background and nurturing, vocational choice, occupation also play an effective role in deciding the type of values instilled in an individual and it works vice versa.

The present study was conducted upon university going under-graduate students. Till now very little attention has been given by researchers in this particular area. Thus, itwas chosen to carry out the present research to measure three out of six types of basic valuedifferences between the male \& female students affiliated to Business Administration and Fine-Arts streams, in Ahmedabad city, Gujarat, India.

\section{RATIONALE}

The rationale of this study is to determine if there are any differences found in aesthetic, economic, and political values between the undergraduate male and female students of the 
Business Administration and Fine-Arts streams, and also to compare and determine- students of which stream are better suited to their relevant fields.

More important goals induce a stronger motivation to plan thoroughly (Gollwitzer, 1996). The higher the priority given to a value, the more likely people will form action plans that can lead to its expression in behavior. It enhances their belief in their ability to reach the valued goal and increases persistence in the face of obstacles and distractions. Thus, the reason for including these two types of universities is to see the differences within the mindset of the students in the two different environments. Generally, people argue that students belonging to a Business Administration institutes are believed to have more of economic and political values as compared to the Fine-Arts stream. Also people presume that students from Fine-Arts colleges have more of Aesthetic value than the students from Business Administration colleges.

Hence, the present research will supposedly help the students, parents, teachers, educators and other researchers to understand the compared vocational ability and relative potentiality of the male as well as female undergraduates of the two different streams, i.e. Business Administration and Fine-Arts.

\section{OBJECTIVES}

1. To study and compare aesthetic value between undergraduates of Business Administration and Fine-Arts streams (in Ahmedabad)

2. To study and compare aesthetic value between undergraduates of Business Administration and Fine-Arts streams, in relation to their gender

3. To study the interaction effect of streams and gender in terms of aesthetic value

4. To study and compare economic value between undergraduates of Business Administration and Fine-Arts streams (in Ahmedabad)

5. To study and compare economic value between undergraduates of Business Administration and Fine-Arts streams, in relation to their gender

6. To study the interaction effect of streams and gender in terms of economic value

7. To study and compare political value between undergraduates of Business Administration and Fine-Arts streams (in Ahmedabad)

8. To study and compare political value between undergraduates of Business Administration and Fine-Arts streams, in relation to their gender

9. To study the interaction effect of streams and gender in terms of political value 


\section{HYPOTHESIS}

1. There will be no significant difference between undergraduates of Business Administration and FineArts streams, in terms of aesthetic value

2. There will be no significant difference between male and female undergraduates of Business Administration and Fine-Arts streams, in terms of aesthetic value.

3. There will be no significant interaction effect between streams and gender in terms of aesthetic value.

4. There will be no significant difference between undergraduates of Business Administration and FineArts streams, in terms of economic value

5. There will be no significant difference between male and female undergraduates of Business Administration and Fine-Arts streams, in terms of economic value

6. There will be no significant interaction effect between streams and gender in terms of economic value

7. There will be no significant difference between undergraduates of Business Administration and FineArts streams, in terms of political value

8. There will be no significant difference between male and female undergraduates of Business Administration and Fine-Arts streams, in terms of political value

9. There will be no significant interaction effect between streams and gender in terms of political value

\section{METHOD}

\section{PARTICIPANTS:}

The present study was confined to Ahmedabad, Gujarat State, India. The participants comprised 300 undergraduate students studying in the Business Administration and Fine-Arts streams of the colleges affiliated with Gujarat University. The sample was equally distributed among two of the streams and gender, i.e. 75 males \& 75 females from Business Administration stream and 75 males and 75 females from Fine-Arts stream were taken. A random sampling design was used to select the members of the sample.

\section{Sample Distribution-}

\begin{tabular}{|c|c|c|c|}
\hline \multirow{2}{*}{$\begin{array}{c}\text { Gender } \\
\downarrow\end{array}$} & Business Administration [N] & Fine-Arts [N] & Total \\
\cline { 2 - 4 } & 75 & 75 & 150 \\
\hline Male & 75 & 75 & 150 \\
\hline Female & 150 & 150 & 300 \\
\hline Total & & & \\
\hline
\end{tabular}




\section{MEASURING INSTRUMENTS/ TOOLS:}

To measure the values of the subjects, "Value Test" by Dr. Raj Kumar Ojha and Dr. Mahesh Bhargav was used in the present investigation. The main aim of the study of values is to measure the six basic interests or motives in personality: Theoretical, Economical, Aesthetic, Social, Political, And Religious. This type of classification is based upon Spranger's Type(s) of man. In the present investigation, three out of six basic values were examined, without altering the attributes of the value test;

Aesthetic Value [Beauty and Harmony] - It means an appreciation of artistic beauty, harmony and form for its own sake.

Economic Value [Usefulness] - It means a basic concern for what is useful and practical.

Political Value[Power] - It means a basic interest in power and leadership related to any field not just to politics.

\section{Reliability of the Value Test- (As given by the Authors):}

The internal consistency of the scale is determined by the Split-half method.

The items for each value were divided into two sub-scales. The product moment correlations are as given below;

\begin{tabular}{lcr} 
Values & Revised Form & Old Form \\
\hline Theoretical & .78 & .60 \\
Economic & .81 & .65 \\
Aesthetic & .76 & .54 \\
Social & .82 & .66 \\
Political & .83 & .62 \\
Religious & .84 & .70
\end{tabular}

Validity of the Value Test-(As given by the Authors):

As shown below, correlations (r's) obtained for a sample of 500 Male and 500 Female, Graduate and Post-Graduate students. 


Males Economic Aesthetic Social Political Religious

Theoretical $-.26$

$-.11$

$-.30$

Economic

Aesthetic

Social

Political

$\underline{\text { Females }}$

Theoretical $-.10$ $-.08$ $-.36$

Economical

Aesthetic

Social

Political

$\begin{array}{rrr}-.10 & -.12 & -.13 \\ .28 & .30 & .38 \\ -.19 & -.16 & -.29 \\ & -.21 & -.13 \\ & & -.32\end{array}$

$-.19$

$-.29$

$-.38$

$-.10$

$-.40$

There is a positive association between economic-social values and between economic-political values, and between economic-religious values in males. But in female sample, there is a positive association between economic-religious values and aesthetic-religious values, and social-religious values. In both the groups, the degree of correlations is low.

\section{PROCEDURE:}

The present study was conducted to investigate the differences in three out of six basic values in two streams of education. To conduct this research several steps were followed that are discussed herein. First of all, lists of colleges offering Business Administration and Fine-Arts courses were made. According to research plan, then, 300 samples were selected randomly from the relevant institutions in Ahmedabad.

Necessary rapport was established before administration of the test. However, it was preferred to visit the subjects through some references; thereby also employing Snow ball sampling method. The subjects were visited each day and were given the questionnaires. Verbal instructions were given to them, to make them understand the questionnaire easily. The subjects were assured that the information would be kept confidential. Each student was given time of two days to fill the given questionnaire which was then collected later. At the time of collecting the questionnaires back, all the respondents were thanked for their cooperation and participation in the study. Then, the data was scored and the raw scores of only aesthetic, economic and political values were segregated for the statistical calculations. Two way Analysis of Variance (ANOVA) as a part of statistical analysis was employed, in order to examine the role of values. 


\section{RESULTS}

1. AESTHETIC VALUE:

$1.1 \underline{\text { ANOVA }}$

\begin{tabular}{|c|c|c|c|c|c|}
\hline Source of Variable & $\begin{array}{c}\text { Sum of } \\
\text { Squares }\end{array}$ & df & $\begin{array}{c}\text { Mean } \\
\text { Squares }\end{array}$ & F Ratio & $\begin{array}{c}\text { Level of } \\
\text { Significance }\end{array}$ \\
\hline Stream [A] & 1905.12 & 1 & 1905.12 & 61.3373 & 0.01 \\
\hline Gender [B] & 385.3333 & 1 & 385.3333 & 12.4062 & 0.01 \\
\hline Stream * Gender [A*B] & 41.81333 & 1 & 41.81333 & 1.346223 & 0.05 \\
\hline Error & 9193.68 & 296 & 31.05973 & & \\
\hline Total & 11525.95 & 299 & & & \\
\hline
\end{tabular}

\subsection{MEANS}

1.2.1 Mean scores of variable A [Stream]

\begin{tabular}{|l|c|c|}
\hline & Fine-Arts [A1] & Business Administration [A2] \\
\hline $\mathrm{M}$ & 42.87 & 37.83 \\
\hline $\mathrm{N}$ & 150 & 150 \\
\hline
\end{tabular}

1.2.2 Mean scores of variable B [Gender]

\begin{tabular}{|l|c|c|}
\hline & Male [B1] & Female [B2] \\
\hline $\mathrm{M}$ & 39.21 & 41.48 \\
\hline $\mathrm{N}$ & 150 & 150 \\
\hline
\end{tabular}

1.2.3 Mean scores of variable A*B [Stream*Gender]

\begin{tabular}{|l|c|l|l|c|}
\hline & $\begin{array}{c}\text { Fine-Arts*Male } \\
{[\mathrm{A} 1 * \mathrm{~B} 1]}\end{array}$ & $\begin{array}{l}\text { Fine- } \\
\text { Arts*Female } \\
{[\mathrm{A} 1 * \mathrm{~B} 2]}\end{array}$ & $\begin{array}{l}\text { Business } \\
\text { Administration*Male } \\
{[\mathrm{A} 2 * \mathrm{~B} 1]}\end{array}$ & $\begin{array}{c}\text { Business } \\
\text { Administration*Female } \\
{[\mathrm{A} 2 * \mathrm{~B} 2]}\end{array}$ \\
\hline $\mathrm{M}$ & 42.11 & 43.63 & 36.32 & 39.33 \\
\hline $\mathrm{N}$ & 75 & 75 & 75 & 75 \\
\hline
\end{tabular}


ANOVA Table-1.1 illustrates results on Aesthetic value of male and female students belonging to Fine-Arts and Business Administration fields. The table shows that $\mathrm{F}$ ratio for aesthetic value of students of Fine-Arts and Business Administration streams is 61.33, which is significant at 0.01 level; this means, our null hypothesis is rejected here- students of Fine-Arts differ significantly on aesthetic value as compared to students of Business Administration stream. By the same point of view the Mean table-1.2.1 represents the mean scores ofFine-Arts and Business Administration students, which are 42.87 and 37.83, respectively. From the derived scores, it can be inferred that significant difference exists between students of Fine-Arts and Business Administration streams.

F ratio for Aesthetic value, of gender is 12.40 , which is significant at 0.01 level; this means, our null hypothesis is rejected here- male students of both the streams differ significantly on aesthetic value as compared to the female students. By the same point of view the Mean table-1.2.2 represents the mean scores of male and female students of both the streams, which are 39.21 and 41.48, respectively. Thus, it can be said that significant difference exists between male and female [gender] students of Fine-Arts and Business Administration streams.

$\mathrm{F}$ ratio for Aesthetic value in terms of interaction effect between streams [Fine-Arts \& Business Administration] and gender [male \& female] (AXB) is 1.34, which is significant at 0.05 level; this means our null hypothesis is rejected and significant interaction effect exists between streams and gender regarding aesthetic value. By this same point of view the Mean table-1.2.3 represents the mean scores of Fine-Arts male students, Fine-Arts female students, Business Administration male students and Business Administration female students; which are 42.11, 43.63, 36.32 and 39.33 respectively.

\section{ECONOMIC VALUE:}

2.1 ANOVA

\begin{tabular}{|c|c|c|c|c|c|}
\hline Source of Variable & $\begin{array}{c}\text { Sum of } \\
\text { Squares }\end{array}$ & df & $\begin{array}{c}\text { Mean } \\
\text { Squares }\end{array}$ & F Ratio & $\begin{array}{c}\text { Level of } \\
\text { Significance }\end{array}$ \\
\hline Stream [A] & 286.1633 & 1 & 286.1633 & 10.19895 & 0.01 \\
\hline Gender [B] & 8.67 & 1 & 8.67 & 0.309002 & NS \\
\hline Stream * Gender [A*B] & 62.56333 & 1 & 62.56333 & 2.229777 & NS \\
\hline Error & 8305.2 & 296 & 28.05811 & & \\
\hline Total & 8662.597 & 299 & & & \\
\hline
\end{tabular}




\section{2 $\underline{\text { MEANS }}$}

2.2.1 Mean scores of variable A [Stream]

\begin{tabular}{|l|c|c|}
\hline & Fine-Arts [A1] & Business Administration [A2] \\
\hline $\mathrm{M}$ & 39.82 & 41.77 \\
\hline $\mathrm{N}$ & 150 & 150 \\
\hline
\end{tabular}

2.2.2 Mean scores of variable B [Gender]

\begin{tabular}{|l|c|c|}
\hline & Male [B1] & Female [B2] \\
\hline $\mathrm{M}$ & 40.63 & 40.97 \\
\hline $\mathrm{N}$ & 150 & 150 \\
\hline
\end{tabular}

2.2.3 Mean scores of variable A*B [Stream*Gender]

\begin{tabular}{|l|c|l|l|c|}
\hline & $\begin{array}{c}\text { Fine-Arts*Male } \\
{[\mathrm{A} 1 * \mathrm{~B} 1]}\end{array}$ & $\begin{array}{l}\text { Fine- } \\
\text { Arts*Female } \\
{[\mathrm{A} 1 * \mathrm{~B} 2]}\end{array}$ & $\begin{array}{l}\text { Business } \\
\text { Administration*Male } \\
{[\mathrm{A} 2 * \mathrm{~B} 1]}\end{array}$ & $\begin{array}{c}\text { Business } \\
\text { Administration*Female } \\
{[\mathrm{A} 2 * \mathrm{~B} 2]}\end{array}$ \\
\hline $\mathrm{M}$ & 40.11 & 39.53 & 41.15 & 42.40 \\
\hline $\mathrm{N}$ & 75 & 75 & 75 & 75 \\
\hline
\end{tabular}

ANOVA Table-2.1 illustrates results on Economic value of male and female students belonging to Fine-Arts and Business Administration fields. The table shows that $\mathrm{F}$ ratio for Economic value of students of Fine-Arts and Business Administration streams is 10.19, which is significant at 0.01 level; this means, our null hypothesis is rejected here and students of Fine-Arts differ significantly on economic value as compared to students of Business Administration stream. By the same point of view the Mean table-2.2.1 represents the mean scores of Fine-Arts and Business Administration students, which are 39.82 and 41.77, respectively. From the derived scores, it can be inferred that significant difference exists between students of Fine-Arts and Business Administration streams. 
F ratio for Economic value, of gender is 0.30 , which is not significant; this means, male students of both the streams do not differ significantly on economic value as compared to the female students. By the same point of view the Mean table-2.2.2 represents the mean scores of male and female students of both the streams, which are 40.63 and 40.97, respectively. Thus, it can be said that significant difference does not exist between male and female [gender] students of Fine-Arts and Business Administration streams.

F ratio for Economic value in terms of interaction effect between streams [Fine-Arts \& Business Administration] and gender [male \& female] (AXB) is 2.22, which is not significant; this means significant interaction effect does not exist between streams and gender regarding economic value. By this same point of view the Mean table-2.2.3 represents the mean scores of Fine-Arts male students, Fine-Arts female students, Business Administration male students and Business Administration female students; which are $40.11,39.53,41.15$ and 42.40 respectively.

\section{POLITICAL VALUE:}

3.1 ANOVA

\begin{tabular}{|c|c|c|c|c|c|}
\hline Source of Variable & $\begin{array}{c}\text { Sum of } \\
\text { Squares }\end{array}$ & df & $\begin{array}{c}\text { Mean } \\
\text { Squares }\end{array}$ & F Ratio & $\begin{array}{c}\text { Level of } \\
\text { Significance }\end{array}$ \\
\hline Stream $[\mathrm{A}]$ & 1976.333 & 1 & 1976.333 & 52.37983 & NS \\
\hline Gender [B] & 185.6533 & 1 & 185.6533 & 4.92047 & 0.05 \\
\hline Stream * Gender [A*B] & 130.68 & 1 & 130.68 & 3.463482 & NS \\
\hline Error & 11168.32 & 296 & 37.73081 & & \\
\hline Total & 13460.99 & 299 & 13460.99 & & \\
\hline
\end{tabular}

\subsection{MEANS}

3.2.1 Mean scores of variable A [Stream]

\begin{tabular}{|l|c|c|}
\hline & Fine-Arts [A1] & Business Administration [A2] \\
\hline $\mathrm{M}$ & 36.26 & 41.39 \\
\hline $\mathrm{N}$ & 150 & 150 \\
\hline
\end{tabular}




\subsubsection{Mean scores of variable B [Gender]}

\begin{tabular}{|l|c|c|}
\hline & Male [B1] & Female [B2] \\
\hline $\mathrm{M}$ & 39.61 & 38.04 \\
\hline $\mathrm{N}$ & 150 & 150 \\
\hline
\end{tabular}

1.2.3 Mean scores of variable A*B [Stream*Gender]

\begin{tabular}{|l|c|c|l|c|}
\hline & $\begin{array}{c}\text { Fine-Art**Male } \\
{[\mathrm{A} 1 * \mathrm{~B} 1]}\end{array}$ & $\begin{array}{l}\text { Fine- } \\
\text { Arts*Female } \\
{[\mathrm{A} 1 * \mathrm{~B} 2]}\end{array}$ & $\begin{array}{l}\text { Business } \\
\text { Administration*Male } \\
{[\mathrm{A} 2 * \mathrm{~B} 1]}\end{array}$ & $\begin{array}{c}\text { Business } \\
\text { Administration*Female } \\
{[\mathrm{A} 2 * \mathrm{~B} 2]}\end{array}$ \\
\hline $\mathrm{M}$ & 37.71 & 34.81 & 41.52 & 41.27 \\
\hline $\mathrm{N}$ & 75 & 75 & 75 & 75 \\
\hline
\end{tabular}

ANOVA Table-3.1 illustrates results on Political value of male and female students belonging to Fine-Arts and Business Administration fields. The table shows that F ratio for Political value of students of Fine-Arts and Business Administration streams is 52.37, which is not significant; this means, students of Fine-Arts do not differ significantly on political value as compared to students of Business Administration stream. By the same point of view the Mean table3.2.1 represents the mean scores of Fine-Arts and Business Administration students, which are 36.26 and 41.39 , respectively. From the derived scores, it can be inferred that significant difference does not exist between students of Fine-Arts and Business Administration streams.

F ratio for Political value, of gender is 4.92 , which is significant at 0.05 level; this means, our null hypothesis is rejected here and male students of both the streams differ significantly on Political value as compared to the female students. By the same point of view the Mean table3.2.2represents the mean scores of male and female students of both the streams, which are 39.61 and 38.04, respectively. Thus, it can be said that significant difference exists between male and female [gender] students of Fine-Arts and Business Administration streams.

F ratio for Political value in terms of interaction effect between streams [Fine-Arts \& Business Administration] and gender [male \& female] (AXB) is 3.46, which is not significant; this means significant interaction effect does not exist between streams and gender regarding political value. By this same point of view the Mean table-3.2.3 represents the mean scores of Fine-Arts male students, Fine-Arts female students, Business Administration male students and Business Administration female students; which are 37.71, 34.81, 41.52 and 41.27 respectively. 


\section{DISCUSSION}

The major conclusions inferred in this study indicate that undergraduate students of Fine-Arts stream have greater Aesthetic value than undergraduates of Business Administration stream. This carries the idea that Fine-Arts students are suited to their relevant field. Tinio\& Pablo (2013) supports this when they state that Aesthetic experiences mirror the art-making process in the sense that the early stages of aesthetic processing correspond to the final stages of art-making. Also we found that Aesthetic value is higher in females than male undergraduates.

Subsequently, results represent that Economic value is greater in Business Administration students as compared to Fine-Arts students. Business school students accrue the economic value from their education. (Jonathan, Drnevich, Crook, Craig, 2010). This indicates that students of Business Administration stream are also potential and suitable students to their relevant field. Economic value does not differ at gender level.

We also derived that Political value does not differ in terms of streams but interestingly male students seem to have higher political value than female students, considering both the streams. The common explanation for why men, more than women, have interest in politics, grows from men's need for mating territories. Also, as stated in a study related to the Values Adjusted for Sex and Variability Differences, by Stanley and Julian (1953), "Men are observed being more political \& economic", which supports the derived results in this study.

\section{REFERENCES}

1. Allport, G. W. (1937). Personality: A psychological interpretation. New York: Holt, Rinehart \& Winston.

2. Allport, G. W., Vernon, P. E. \&Lindzey, G. (1951).Study of values (Revised Edition)New York: Houghton Mifflin.

3. Bronwyn L. A., \& Holt R. (Dec. 2014) A Short History of the Study of Values. Retrieved from http://www.netplaces.com/career-tests/values-and-your-career/a-short-history-ofthe-study-of-values.htm

4. Cantril H. \&Allport G.W. (1933).Recent Applications of the Study of Values.J. Abnormal. SocialPsychology, 28.Pg. 259.

5. Cantril, H., Allport, G.W. \& Rand.H.A. (1933). The Determination of Personal Interests by Psychological and Graphological Methods, Journal of Personality, 2, pg. 134. 
6. Dunn, S., Bliss, J., \& Siipola, E. (1958). Effects of impulsivity, introversion, and individual values upon association under free conditions. Journal of Personality, 26, 6176.

7. Eaton, T.V., \& D.E. Giacomino (2000). Personal Values of Business Students: Differences by Gender and Discipline. Research on Accounting Ethics, 7: 83-102.

8. England, G.W. (1975). The Manager and His Values: An International Perspective from the United States, Japan, Korea, India, and Australia. Cambridge, MA: 5-67.

9. Finegan, J. (1994). The Impact of Personal Values on Judgments of Ethical Behavior in the Workplace. Journal of Business Ethics, 13: 747-755.

10. Fritzsche, D.J. (1995). Personal Values: Potential Keys to Ethical Decision Making. Journal of Business Ethics (November): 909-923.

11. Getzels J.W., \& Csikszentmihalyi M. (1968). The Value-Orientations of Art Students as Determinants of Artistic Specialization and Creative Performance.Studies in Art Education, 10 (1). Retrieved from http://www.jstor.org/stable/1319665

12. Gollwitzer, P. M. (1996). The volitional benefits of planning.In P. M. Gollwitzer \& J. A. Bargh (eds.), The Psychology of action. New York: Guilford.

13. Guth, W., \& R. Tagiuri.(1965). Personal Values and Corporate Strategies.Harvard Business Review, 43: 123-132.

14. HalsteadJ. M., \& TaylorM.J. (2000).Learning and Teaching about Values: A review of recent research. Cambridge Journal of Education,30(2), 169-202. DOI: $10.1080 / 713657146$

15. Haque, M, \& Mozumder, M.K. (2000).Relationship of Values between Two Generations. The Bangladesh Journal of Psychology, 18, pp-97.

16. Karim, A.K.M.R., \&Rahman, H. (2001). Education system-linked differences in basic areas of value system. The Dhaka University Journal of Psychology, 25.57-64.

17. Karim, S. F. (1990). Adolescents: A cross cultural study of political values. Dhaka University Journal of Psychology, 16, pp: 38-45.

18. Khanam, M. (1993). A comparison of the expressed moral values of Hindu and Muslim students of Dhaka University.Dhaka University Journal of Psychology, 18: Pp:55-59.

19. Mackinnon, D. W. (1964). The creativity of architects.In C.W. Taylor (ed.), Widening Horizons in Creativity. New York: John Wiley, 359-378.

20. Moeed, M.A., \&Murshed, S.M. (1986).University education and change of values. Bangladesh Journal of Psychology, 9, pp: 54-60.

21. Mohsin, S. (1955).Allport- Vernon study of values in Indian situation.Religious group difference in values.

22. O'Brien, J.P., Drnewich, P. L., Crook, T. R., \& Armstrong, C.E. (2010). Does business school research add economic value for students?. Academy of Management Learning and Education, Vol. 9(4), pp. 638-651.

23. Rahman, M.A., \& Wadud, N. (1983). Value differences of incoming and outgoing students of Dhaka University. Dhaka University Journal of Psychology, 13, pp: 39- 43. 
24. Roe R.A., \& Ester P. (1999).Values and Work Empirical Findings and Theoretical Perspective. Applied Psychology: An International Review, 48 (1). 1-21. Retrieved from http://arno.unimaas.nl/show.cgi?fid=14694

25. Rokeach, M. (1973). The Nature of Human Values.New York, Free Press.

26. Roy, Chowdhury, K. (1957). An Experiment with the Construction of the Test of Interests at the University Level. Ind. Psychol. Bull. 2, pg. 10.

27. Roy, Chowdhury, K. (1957-58), Allport-Vernon Study of Values in Indian Sciences. Congress Association.

28. Schwartz, S. H. (2006). Les valeurs de base de la personne: Théorie, mesuresetapplications [Basichuman values: Theory, measurement, and applications]. RevueFrançaise de Sociologie,47, 249-288.

29. Singhapakdi, A., \& S. J. Vitell (1993). Personal and Professional Values Underlying the Ethical Judgments of Marketers.Journal of Business Ethics. Netherlands 12: 525-533.

30. Spranger, E. (1928). Types of men, Translated by P.J.W. Pigors, Halle, East Germany: Max Niemeyer Verlag.

31. Stanley,\& Julian C. (1953). Study of Values profiles adjusted for sex and variability differences. Journal of Applied Psychology, 37(6), 472-473.

32. Timmer, S.G., \&Kahle, L.R. (1983). Birth right demographic correlates of values. In L.R. Kahle (ed.) Social values and social change. N.Y.: Praeger.

33. Tinio, Pablo P. L. (2013). From artistic creation to aesthetic reception: The mirror model of art. Psychology of Aesthetics, Creativity, and the Arts, Vol 7(3), 265-275.

34. Whitley.P.L. (1933).A Study of the Allport Vernon Test for Personal Values.J. Abnorm. Soc. Psychol, 28, pg 9.

35. Zaman, S.(1973). Changes of Values.The Dhaka University Studie, xx1 (1).Pp: 141-163. 